\title{
Sustainable Development of Central Coast Tourism Based on Value Chain Approach
}

\author{
NGUYẼ̃N PHÚC NGUYÊN \\ Đà Nẵng University of Economics \\ nguyennp@due.edu.vn \\ LÊE THẾ GIÓI \\ University of Đà Nẵng \\ ltgioi@ac.udn.vn
}

\section{ARTICLE INFO}

Article history:

Received:

March 20, 2013

Received in revised form

July 15, 2013

Accepted:

Sep. 25,2013

Keywords:

tourism,

Central Vietnam,

value chain

\begin{abstract}
Over the past decade, the tourism industry in Vietnam in general and in Central Vietnam in particular has grown significantly and played a major role in the economy, contributing not only to the national GDP but also to development of other sectors such as transportation, construction and banking, etc. However, this growth has not reached full potentials of the region. Empirical study in Đà Nẵng has revealed limitations in the development of tourism in this province and in Central Coastal region as well. By analyzing minutely main causes of limitations based on the value chain analysis, this paper proposes some solutions to sustainable tourism development in the Central Coastal region by developing a single destination and making the best use of creative and supporting resources besides local natural ones.
\end{abstract}




\section{INTRODUCTION}

Vietnam's tourism industry has made great achievements in the past years. The number of international visitors to the country has increased over the years (see Figure 1). In 1995, Vietnam only welcomed and provided services for 1.35 million foreign visitors, but 17 years later, this figure rose to more than 6.8 million in 2012, gaining an average growth rate of $12 \%$ yearly for the period 1995-2012 with the year 2012 witnessed an increase of over $13.86 \%$ in comparison with 2011.

Moreover, the tourism sector has attracted US $\$ 16$ billion in foreign direct investment with about 625 projects, ranked third among sectors where the biggest foreign investments are found (data up to November 2010). Tourism is an important factor for economic development of Vietnam. The tourism industry contributes significantly to the GDP (in 2010, tourism accounted for 3.9\% of GDP, and this figure increased to $9.2 \%$ in 2011). To date there are 1,040 international tour operators with approximately 13,000 tourist accommodation establishments, more than 10,000 domestic travel agencies that create jobs for hundreds of thousands of people.

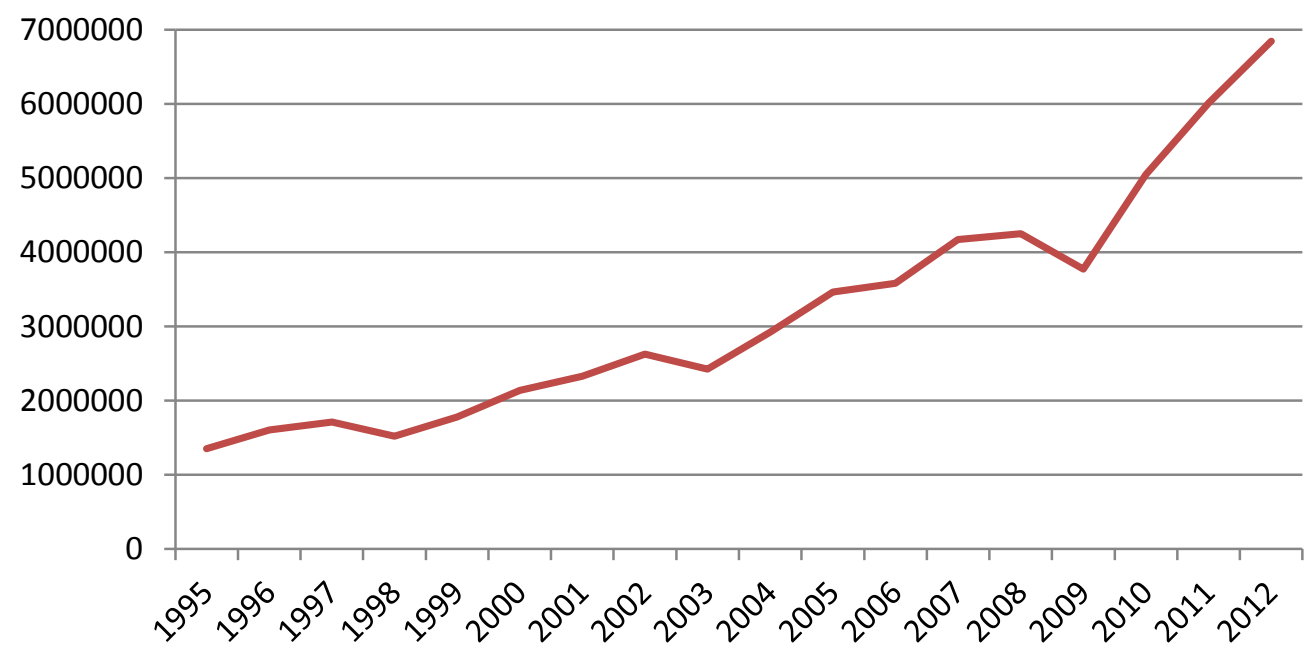

Figure 1: Number of International Tourists to Vietnam over the Years

Source: General Statistics Office

Along with the development of tourism nationwide, tourism in Central Vietnam is flourishing. Stretching from Thanh Hóa to Bình Thuận with over 1,000 kilometers of coastline, the Central Coast features over 200 large and small islands with many bays and beaches, dozens of which are considered as the most beautiful in the country and 
over the globe, such as Sầm Sơn, Cửa Lò, Nhật Lệ, Cửa Tùng, Lăng Cô, Mỹ Khê, Non Nước, Cửa Đại, Tam Thanh, Quy Nhơn, Nha Trang, Ninh Chữ, Cà Ná, Mũi Né - Hòn Rơm, and so on. According to the data from Statistical Yearbook, the whole region welcomed 2.6 million foreign tourists in 2010, accounting for an average growth of 9.5 $\%$ yearly in 2005-2010 and 7.3 million domestic visitors with an average growth of 14.8 $\%$ yearly in 2005-2010.

In 2010, tourism receipts for Central Coastal provinces was VND6,164 billion, an increase of 2.87 times as compared to 2005, accounting for over $6 \%$ of Vietnam's tourism receipts. However, tourism in Central Coast has yet to go beyond the exploitation of existing potentials based on natural tourist attractions, such as Phong Nha, Hội An, and Mỹ Sơn, etc.

Thus, tourism products in this area share similarities and do not really tap the full potentials of the region. This leads to duplication of offered products, causing boredom for visitors. In other words, tourism development in Central Vietnam at the present is mainly based on comparative advantages, and full attention is not paid to development of competitive advantages. A search of ways to create regional competitive advantages and especially destination competitiveness should be the main topic of the study.

The article will discuss methods to develop Central Vietnam tourism based on an analysis of the nature of travel and tourism value chain. Theories and researches on tourism value chain as well as the characteristics of tourism products are integrated. Employing Đà Nẵng as an example, the authors probe into the tourism development in this area. The study only focuses on the analysis of international visitors to Đà Nẵng, based on that the authors propose solutions as well as policies to sustainable tourism development of Central Coast.

\section{AN OVERVIEW OF TOURISM AND TOURISM VALUE CHAIN}

\section{a. Concepts of Tourism and Tourism Products:}

According to Article 4, Chapter 1 of Vietnam's Tourism Law dated June $14^{\text {th }} 2005$, "tourism is all activities related to human's trip outside his regular residence to meet the needs of sightseeing, discovery, leisure, and relaxation in a certain period of time" whereby tourist services are "the provision of services including travelling, transportation, accommodation, dining, recreation, information, guidance and other services to meet the demands of tourists." 
According to Nguyễn \& Trần (2006), "tourism products are services or goods provided to visitors and created by the combination of the exploitation of natural and social elements and the use of resources including technical and labor facilities at a certain location, a region, or a country."

Hence, the success of a tourism business relies not only on its own ability but also on the capacity of the supply chain. Zhang et al. (2009) defined a tourism supply chain as "a network of tourism organizations engaged in different activities ranging from the supply of different components of tourism products/services such as flights and accommodation to the distribution and marketing of the final tourism product at a specific tourism destination, involving a wide range of participants."

\section{b. Characteristics of Tourism:}

According to Ujima (2001), Nguyễn \& Trần (2006), and Zhang et al. (2009), tourism comes up with the following characteristics:

- First, it is a sector that requires close cooperation in which products/services are combined with one another to create the final tourism products.

- Second, tourism products are not tangible and do not exist in form of objects. Moreover, due to the fact that production and service consumption are simultaneous, they are not to be stored and easily damaged. In that case, businesses employ prices and other tools to attract customers during specific periods to make adjustments to demands.

- Third, tourism products are immovable. Tourists need to move to a particular destination to use them. Normally, tourism products cannot be verified or evaluated before usage. For normal goods, the customers intending to make a purchase may closely examine them as with natural characteristics of the products, aesthetic appeal or tastes, but they cannot do the same thing with tourism products. This implies that the supply of tourism products depends largely on the recommendations, explanations and promotions of the products; therefore, tourism is sensitive to information or much dependent on it.

- Fourth, tourism is an activity with many specifics, including a variety of participants that form a truly complex whole. Tourism products comprise various service departments such as accommodation, transportation, sightseeing, dining, shopping and the likes.

- Finally, tourism often faces with much higher and more complicated uncertainties about demand than other sectors due to fierce competitions between service providers. 
Consumers' demand for tourism products does not occur regularly but is focused at certain times, so the tourism business features high seasonality. Moreover, many factors take part in creating uncertainties about the needs for tourism products. For example, a tourism promotion campaign can effectively attract many visitors while an unfavorable remark about service supplied in a specific phase can lead to a drop in demand. Economic condition of the countries where tourism demand arises is a push factor, affecting the demand for tourism products at a particular destination.

\section{c. Tourism Value Chain:}

To promote a sustainable development in tourism, researching the tourism value chain is the first key step. On the basis of theoretical research, the authors used diagrams of the tourism value suggested by Denicolai et al. (2010) because it fully reflects the content of the value chain. In other words, it implies that a tourism destination is an area network that creates values "with and for" tourists.

In Figure 2, the main operations consist of accommodation facilities (eg. hotels, camping sites, etc.), places to eat (restaurants, fast food stalls, etc.), event and resource management (landscape protection associations, tourism associations, tourism promotion committee, etc.), and infrastructure management (transport, communication infrastructure, etc.). Also, all primary activities are interdependent.

Moreover, support activities enhance the value creation, including promotion, sales, welcome/information, market monitoring and core-competencies renewing. These activities are managed directly and separately by individual participants in the tourism system or in a centralized manner. 


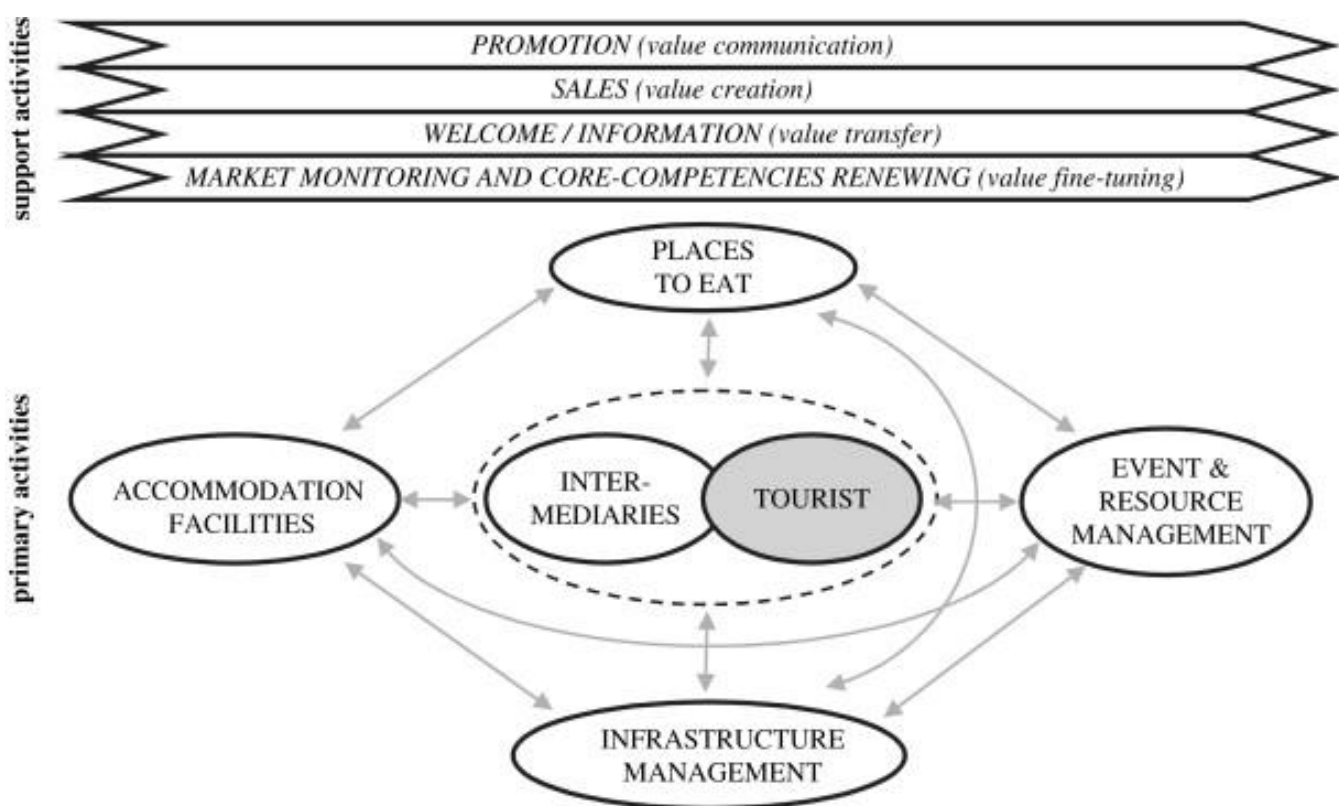

Figure 2: Constellation Value of Tourist Network by Denicolai et al. (2010)

Additionally, according to Zhang et al. (2009), tourism supply chain is "a network of tourism organizations engaged in different activities ranging from the supply of different components of tourism products/services such as flights and accommodation to the distribution and marketing of the final tourism product at a specific tourism destination, and involved a wide range of participants in both the private and public sectors". For this reason, to be successful, enterprises should base themselves not only on their own capabilities but also on the capacity of the supply chain because in tourism, there is a tendency to switch to destination competitions. Furthermore, competitive advantages of tourism destinations in general depend on the structure of the network rather than the capacity of individual businesses (Denicolai et al., 2010). So, what is the current tourism chain of Central Vietnam? The next section will provide an in-depth discussion of this issue.

\section{TOURISM DEVELOPMENT IN CENTRAL VIETNAM - ĐÀ NÃ̃NG SITUATION}

\section{a. Current Tourism Value Chain of Đà Nẵng:}

To examine operations and suggest solutions to tourism development in Central Vietnam, a prerequisite is to identify the tourism value chain. Despite the differences in 
local colors, the current value chain in this region is quite similar. Therefore, the authors will focus on the value chain in Đà Nẵng.

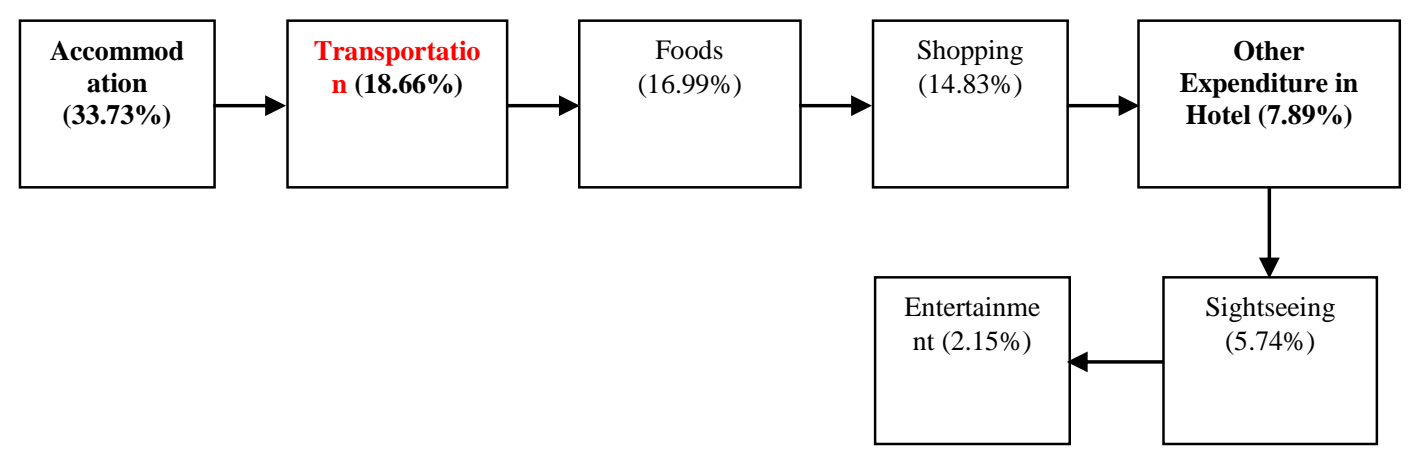

Figure 3: Tourism Value Chain of Đà Nã̃ng

Source: Jonathan Mitchell \& Le (2007)

According to Mitchell \& Le (2007), about $60 \%$ of domestic tourists and $40 \%$ of international ones contribute to the tourism value chain. Daily spending of international tourists is roughly 2.5 times higher than that of domestic ones and the best part of this spending is on accommodation services (33.73\% of the total value of the chain), followed by transportation costs, food and shopping. Visitors to Đà Nẵng also spend on such other hotel services as spa, massage, etc., which accounts for $7.89 \%$.

The value chain shows that the added values brought to visitors are modest. This may be a general situation of the tourism value chain in the Central Coast region, where similarities in geographical features, nature and the methods to exploit, use and manage the tourism are apparent.

\section{b. Main Reasons:}

- Focus on the Exploitation of Comparative Advantages

In current tourism business and development, the city of Đà Nẵng only focuses on exploiting the comparative advantages on the basis of inherent resources (as classified by Dwyer \& Kim, 2003). Therefore, the excessive exploitation and use of tangible heritage from nature such as oceans, rivers and mountains can easily be observed. According to a survey by Nguyễn (2011), the image of Đà Nẵng in the minds of visitors is associated with sea (37.8 \%), Non Nước Mountain (23.2 \%), Bà Nà (19.5\%), and Champa Sculpture Art Museum (17.8 \%). Data from studies by Lê \& Hà (2010) also 
indicated that Thai tourists choose Đà Nẵng as a destination mainly due to its beautiful beaches and scenic landscapes.

This explains why tourist receipts and added value of Đà Nẵng tourism sector remain modest. Although exploiting comparative advantages is one of the ways to create tourism destination competitiveness (Dwyer and Kim, 2003; or Nguyễn, 2012), such advantages are common all over Central Vietnam, thus easily resulting in boredom in tourism products. If the focus is only on the marine benefits, then the surrounding provinces should also provide the same services, confirming that the Central Coast has yet to draw up its direction for investment strategies as well as tourism development (Trần, 2013).

- Lack of Unique Products

In Figure 3, it can be seen that the current tourism business of Central Vietnam in general and of Đà Nẵng in particular only focuses on primary activities, and no full attention is paid to support ones. The number of tourists to Đà Nẵng is still modest compared with national average. Since 2000, the number of international visitors to Vietnam has risen significantly (Figure 1). However, the number of annual visitors to Đà Nẵng remains at the one hundred thousand mark (see http://www.mesopartner.com/fileadmin/user_files/case_studies/Tourism_VCA_DaNang.pdf). In 2010, alone the country welcomed more than 5 million international visitors, whereas the number was only 370,000 for Đà Nẵng.

There are many reasons causing fewer international tourists to Đà Nẵng, and the failure to offer products that satisfy tourists' diverse demands is one of the main reasons. This reduces the value brought to customers and contribution by tourism business to the municipal economy. International visitors to Đà Nẵng only spend US\$12 per day and the expenditure on handicrafts and souvenirs is US\$3 per day, equal to only an eighth compared to the amount spent by visitors staying overnight in Đà Nẵng, while the similar number for visitors to Hội An is US\$20 (Mitchell \& Le, 2007).

Moreover, the length of stay recorded with tourists in Đà Nẵng is only 1.56 days while the national and Central Coast averages are 7.6 days and 3.5 days respectively (Hà, 2013). This phenomenon occurs because of the absence of unique tourism products provided for international tourists, such as sightseeing, exploring and recreational services. While Hội An specialties are lanterns, apparel or night festivals of Hoài town and Huế comes up with Huế court music or excursions on the Hương River. The only 
specialty in Đà Nẵng is handicraft products from Non Nước village. Only a few products are provided, which results in short exploring time for visitors and modest receipts for local tourism business.

Additionally, Đà Nẵng in particular and Central Coastal provinces in general only focus on the type of sightseeing tour and island cruise; the exploitation of the potential brought by nature itself creates products which are similar and duplicate, leading to conflicts of interests and keen competition among provinces in the region and hindering tourism development (Trần, 2013). The region cannot well exploit the groups of tourists who come here for business and relative visits. The purpose of international visitors to Vietnam is illustrated in Figure 4.

Assuming that the ratio of visitors to Đà Nẵng for business corresponds to that of the whole country, in 2010 alone, the number of visitors to Đà Nẵng on business is approximately 74,000 and for relative visits, 73,000. By 2012, these figures were 453,000 and 447,000 respectively. Yet, Đà Nẵng and neighboring provinces have not currently invested in MICE tourism products as well as other products for the purpose of relative visits.

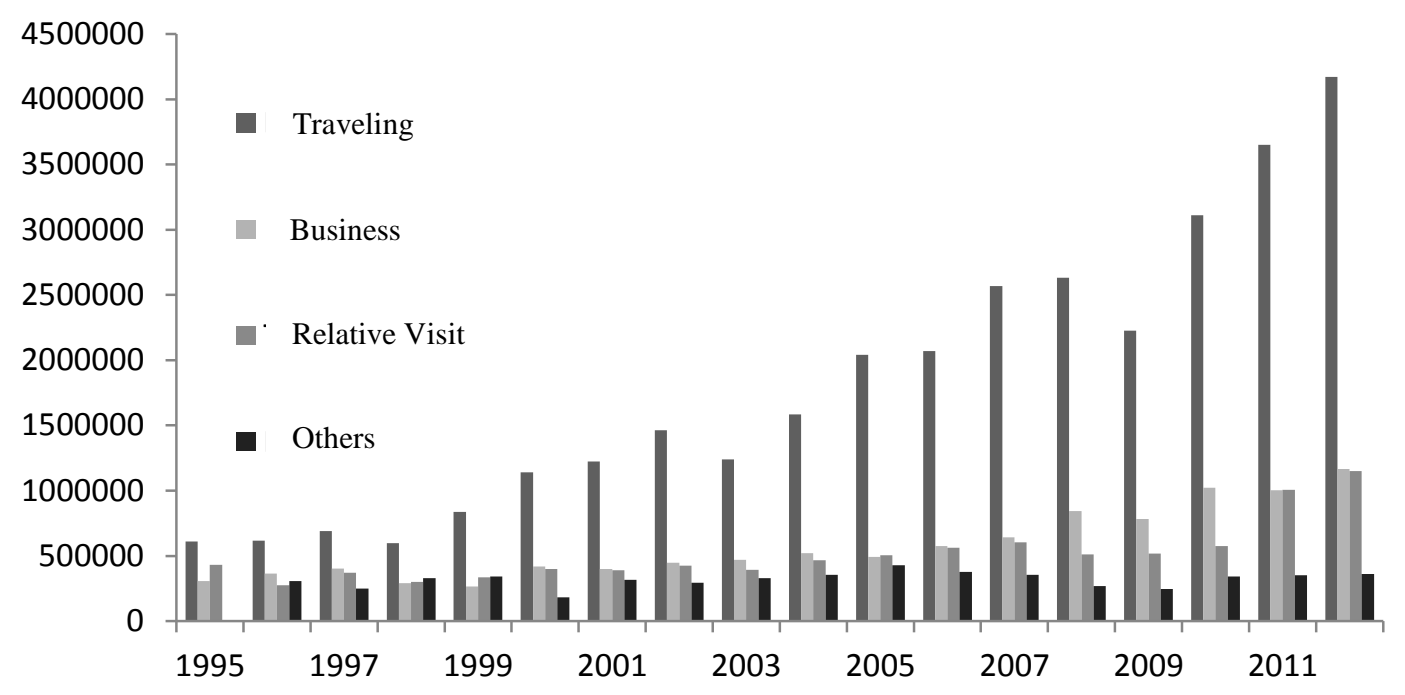

Figure 4: Purposes of International Tourists to Vietnam

Source: General Statistics Office 
- Lack of Attractions and Imperfect Infrastructure

The analysis of tourism value chain in Đà Nẵng reveals that the value created by sightseeing and recreational services is very low, accounting for only $7.89 \%$. Until now, Đà Nẵng, like other provinces in the Central Coastal region, lacks the amusement parks or recreation grounds. There is only a few attractions in Đà Nẵng, including only Non Nước, Bà Nà, Sơn Trà, and some pagodas.

Much as Đà Nẵng possesses a relatively convenient terrain of nature, the landscape here is of little development and exploitation. With a coastline of more than $60 \mathrm{~km}$ long, it offers many beautiful beaches with white sand and blue water. Moreover, Đà Nẵng beach in 2005 was voted by Forbes, an American magazine, as one of the six most attractive beaches on the planet. Yet, cruising has hardly been exploited and additionally, river-based tourism in Đà Nẵng is in low development, going with the unavailability of cruise ships and docks for tourism due to the lack of piers and moorings.

The current limitations of the Central Coast in general and Đà Nẵng tourism development in particular derive from the insufficient infrastructure for tourism. Although provincial/urban governments of the region have invested in many infrastructure projects and/or the gentrification of the city and public works to improve living conditions and facilitate the development of tourism, including coastal roads Hoàng Sa and Trường Sa, roads to Sơn Trà peak, Bà Nà - Suối Mơ resort (in Đà Nẵng), Phong Nha Kẻ Bàng (Quảng Bình), etc., infrastructure between provinces/cities has yet to be evenly developed and comes up with a loose connection. So, tourists moving from this area to another still face certain difficulties.

- Lack of Connection among Provinces

Tourism products have different characteristics. Furthermore, a system destinations are usually created by multiple interdependent agencies or enterprises (Nguyễn, 2012). In other words, customers perceive values created in a destination on the basis of the whole system. Therefore, the competitive advantages of a tourist destination are based on the structure of the entire network rather than the capacity of a few individual enterprises. This requires policy makers and businesses themselves to take a broader view on tourism development within a long-term strategy.

However, Đà Nẵng, as well as other provinces, follows its own strategies for tourism development. Pursuing these strategies, provinces will encounter certain overlaps in investment, thus leading to a waste of resources. Moreover, this also creates the 
monotony of tourism products, considered as fundamental limitations of Đà Nẵng and the Central Coast (Trần, 2013).

Moreover, the research of value chain of Đà Nẵng tourism allows us to realize the tourism value chain in the Central Coast based on similarities in natural conditions, geographical features, and tourism products supplied to visitors. Hence, there should be an assumption that the Central Coast is a tourist destination to compete with other destinations in the region, the strategic goal of sustainable tourism development is to improve the length of stay, as well as spending rate by visitors through a series of unique products typical of each province/region in order to create a separate identity for the region.

The study by Mitchell \& Le (2007) indicated that a number of surveyed visitors maintained that they wanted to visit two sites adjacent to Đà Nã̃ng, which are Huế and Hội An, and therefore building, linking and developing relationships between provinces in the region is an essential factor for the tourism development in not only a separate province but the whole Central Coast as well.

\section{SOLUTIONS TO SUSTAINABLE TOURISM DEVELOPMENT IN CENTRAL VIETNAM}

Based on the above-analyzed limitations, a few solutions to sustainable tourism development in Central Vietnam are proposed as follows:

\section{a. Strategies of a Sole Central Vietnam Destination:}

To improve competitiveness and enhance cooperation in the development of tourism in this area, an essential requirement for leaders is to identify and develop strategies for tourism development of the whole Central Vietnam as a sole destination. On this basis, individual provinces will determine and develop specialties based on local strengths. Based on the survey results, Nguyễn (2011) found that some visitors thought that lanterns and Hội An ancient town were Đà Nẵng's attractions.

For this reason, if provinces in the Central Vietnam can produce mechanisms for cooperation and divide supply of products as if they are parts of a single destination, then investment efficiency will be promoted and current competition between provinces may be avoided. If this strategy is implemented, logistics costs will also be significantly reduced in case tourism enterprises cooperate to draw up schedule of transportation for different groups of tourists. Besides, specialization on the basis of common strategies and agreement in phase splitting for value creation in the tourism value chain will boost chances to diversify tourism products, whereas consistent strategies as for Central 
Vietnam destination will facilitate the joint effort to protect the environment and regulate the supply of and demand for tourism services, thus creating the initiative in sustainable tourism development. By this, an essential of the strategy is the simultaneous development of infrastructure throughout the region in order to increase the service quality of this single destination. Moreover, policies, mechanisms and legal infrastructure for tourism development in Central Vietnam should also be consistent and synchronously conducted.

\section{b. Diversifying Tourism Products Based on Resource Approach}

As discussed above, currently, the majority of tourism products from the Central Coastal region are mainly based on the inherent resources on the basis of tangible heritage (scenic landscapes) and intangible heritage (cultures, festivals). Followed by these factors, tourism in the area has been quickly developed over the past few years.

However, taking into consideration the product factor, Central Vietnam tourism currently suffers a shortage of unique tourism products and a surplus of duplicate ones. We can recognize many of these in different areas from accommodation services to adventure travel and leisure travel. The duplication of tourism products makes Central Vietnam less attractive to tourists. Moreover, from the aspect of value chain, the value brought by these products is very low and does not have unique features of Central Vietnam as a destination. To help tourism in the area take off, its tourism products should rely on creative and support resources to upgrade tourism infrastructure and create such events as fireworks festival in Đà Nẵng or full moon night in Hội An and other recreation activities.

The emphasis is that Central Coastal provinces should strengthen the development of various types of entertainment to enhance the tourism value chain. Additionally, Central Vietnam's climate features two seasons, but products serving the needs of visitors in the rainy season are not available. The development of these tourism products, typical as those in MICE on climate change events held during the rainy season or the art is one example. Moreover, the Central Vietnam has the advantage of extending beach, but marine tourism products are quite limited, which should be taken into account by tourism development strategies.

\section{c. Improving the Capacity of Tourism Workforce:}

One of the reasons leading to the scarcity of tourism products, and poor and uneven product quality among localities in the region derives from the workforce capacity. To 
be able to offer unique tourism products, the workforce must be highly competent, professional, and creative to possibly meet the requirements of tourism development. By such, regional and local authorities are supposed to develop and support tourism training centers, which, in addition, need to update and change the contents and teaching methods.

Currently, these centers have focused on training tourism technical skills instead of ability to develop new tourism products. In fact, these two kinds of skills should be trained in parallel. To offer better products, a prerequisite is to build and support the centers or facilities that do research on demand and behavior of each class of clients. Although the most visitors to Vietnam are from China, Taiwan, Korea, Japan, France, and the United States, researches on the needs and habits of these groups of customers are still limited. Certainly, Japanese tourists' demand differs from that of Chinese or Europeans.

\section{d. Enhance the Publicity and Marketing:}

When there occurs a shift from competition among different provinces in the same region to those between different destinations, and the Central Coast is the only one, publicity and marketing campaign in both domestic and international markets is indispensable. Marketing strategies will put an emphasis on the products offered by the whole region on the basis of the combination of local products based on agreed-upon development strategies.

Marketing strategies should aim at positioning this destination to highlight the image of Central Vietnam in the minds of visitors and tourism workers. The publicity should be based on the tourism development strategy for the entire region and close cooperation and connection among provinces.

\section{CONCLUSION}

Tourism in Vietnam in general and in Central Vietnam in particular has achieved considerable success in recent years. However, from the perspective of the value chain, the value that Central Coast tourism creates is still quite modest with the competition and development mainly based on natural resources. Taking Đà Nẵng as an example, the paper sheds light on the advantages and limitations in the development of tourism in this area in particular and in the Central Coastal region in general.

The strategy to connect tourism sites to make Central Vietnam a single destination will enhance the competitiveness of regional tourism as well as contribute to the 
development of new products by making the best use of creative and support resources. Additionally, the policies and strategies applied to tourism should create "a mutual learning environment" in order to maximize the advantages of the region based on adequate investment in skills improvement of tourism workforce and in an efficient publicity of Central Vietnam destination

\section{References}

Denicolai, A., G. Cioccarelli \& A. Zucchella (2010), "Resource-Based Local Development and Networked Core-Competencies for Tourism Excellence”, Tourism Management, Vol. 31(2), pp.260-266.

Dwyer, L., \& C. Kim (2003), "Destination Competitiveness: A Model and Determinants", Current Issues in Tourism, Vol.6, pp.369-414.

Hà Văn Siêu (2013), "Tạo đột phá trong thu hút đầu tư phát triển du lịch các tỉnh/ thành phố vùng duyên hải miền Trung", Proceedings of the workshop "Promotion of Investment in Central Coast Tourism", pp.151-155.

Lê Văn Huy \& Hà Quang Thơ (2010), "Nghiên cứu hành vi khách du lịch Thái Lan đến Đà Nẵng và đề xuất đối với xây dựng chính sách thu hút du khách", Khoa học và Công nghệ, University of Đà Nẵng, Vol.1(36), pp.121-130.

Mitchell, J. \& Le Chi Phuc (2007), Final Report on Participatory Tourism Value Chain Analysis in Da Nang, Central Vietnam, Vietnam Private Sector Support Programme by MCG Management Consulting and the Overseas Development Institute (ODI) (UK).

Nguyễn Phúc Nguyên (2012), "Vận dụng lý thuyết về chuỗi cung ứng để phát triển ngành du lịch miền Trung”, Khoa hoc và Công nghệ, University of Đà Nẵng, Vol.8 (57), pp.97-103.

Nguyễn Thị Bích Thủy (2011), “Áp dụng kỹ thuật phi cấu trúc đo lường hình ảnh điểm đến Đà Nẵng đối với du khách quốc tế”, Khoa học và Công nghệ, University of Đà Nẵng, Vol.2(43), pp.174182.

Nguyễn Văn Đính \& Trần Thị Minh Hòa (2006), Giáo trình Kinh tế Du lịch, NXB Lao động Xã hội.

Trần Đình Thiên (2013), "Xúc tiến đầu tư phát triển du lịch vùng duyên hải miền Trung”, Proceedings of the workshop "Promotion of Investment in Central Coast Tourism", pp.115-124.

Ujma, D. (2001), "Distribution Channels for Tourism: Theory and Issuses", in D. Buhalis \& E. Laws (eds.), Tourism Distribution Channels: Practices, Issues and Transformation, pp.33-52, London: Continuum International Publishing Group

Zhang, X., H. Song \& G.Q. Huang (2009), "Tourism Supply Chain Management: A New Research Agenda”, Tourism Management, Vol.30, pp.345-358 